\title{
Stem-cell fraud hits febrile field
}

\section{After heart-treatment claims collapse, researchers caution against a rush to the clinic.}

\section{BY DAVID CYRANOSKI}

$\mathrm{R}$ arely has such a spectacular scientific claim been debunked so rapidly. For a few brief hours last week, Hisashi Moriguchi, a project researcher at the University of Tokyo, was riding high, lauded by his nation's press for pioneering work on induced pluripotent stem (iPS) cells. His feat was said to be the first successful use in humans of a technology that days earlier had won his countryman, Kyoto University's Shinya Yamanaka, a share of the Nobel Prize in Physiology or Medicine ${ }^{1}$.

Yet a swift investigation by Nature and several stem-cell researchers found that Moriguchi's claim to have cured six heartfailure patients with cells derived from iPS cells was untrue; that he had lied about his university affiliations; and that he had plagiarized key parts of his research papers ${ }^{2}$. At a hastily convened press conference on 13 October, Moriguchi recanted. "I admit that I lied," he told reporters, adding that his "career as a researcher is probably over".

The sad episode could be written off as one researcher's runaway fantasy. But it highlights the febrile nature of the iPS-cell field, particularly in Japan. Many researchers fear that the therapeutic promise of these cells - which could open the way to creating replacement tissues to treat disease - will spur a premature rush to clinical applications before their safety and efficacy can be proven.

The story kicked off when Moriguchi's claims were splashed over the front page of Yomiuri Shimbun - the highest-circulation newspaper in the world - on 11 October. He described how he had reprogrammed patients' liver cells into an embryonic state, with the potential to develop into many different cell types. After converting these iPS cells into heart-muscle cells, he supposedly injected them into six patients in the United States to successfully repair their damaged heart tissue.

But inconsistencies in the account quickly became apparent. Alerted by Nature, Harvard Medical School and the Massachusetts General Hospital, both in Boston, denied that the procedures had taken place there, or that Moriguchi was affiliated with them, as he had claimed. In an interview with Nature, Moriguchi could not provide details of the ethics review board that had approved the procedures; the source of the clinical-grade cells; or the names of collaborators. He claimed to have carried out an incredible range of activities almost singlehandedly and described unconventional and unlikely methods for producing the cells. Yet he trained as a nurse, lacks a medical degree, and his most recent research was in medical economics. Nature also discovered that the publications that Moriguchi had used to support his claims ${ }^{3,4}$ contained technical images copied from other sources, as well as plagiarized passages from other articles ${ }^{5,6}$. "We are

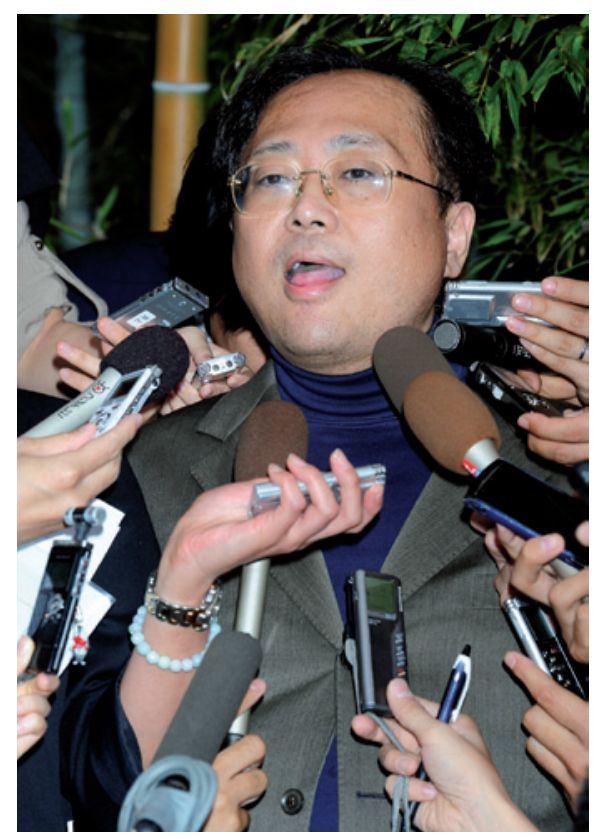

Hisashi Moriguchi was besieged by reporters after giving a press conference retracting his claims.

all doing similar things, so it makes sense that we'd use similar words," Moriguchi told Nature.

On 13 October, the day after Nature ran its exposé ${ }^{2}$, Moriguchi held a press conference in New York, where he had been attending a meeting of the New York Stem Cell Foundation. He admitted that most of his claims were untrue, but maintained that he had injected iPS-cell-derived heart cells into one patient, and that he could produce notes to prove it. The University of Tokyo and the Tokyo Dental and Medical University, where Moriguchi claimed to have carried out collaborative studies, have subsequently launched investigations into the affair. Nature Publishing Group, which has published papers by Moriguchi in its journal Scientific Reports, says that it "is aware of the issues surrounding these publications and is investigating".

Researchers trying to understand why Moriguchi would engage in such reckless fabrication have noted a climate that allows such claims to gain prominence with little challenge. Since Yamanaka's discovery of iPS cells in 2006, some Japanese media and government officials have taken a highly competitive tone about the technology. In its original article about Moriguchi's claims, Yomiuri Shimbun noted that a burdensome regulatory system was holding back Japan's clinical research relative to the United States, and, in a 2009 correspondence published in Nature ${ }^{7}$, Moriguchi argued that "Japan is in danger of being overtaken in the field of human iPS-cell research".

"Scientists, journalists and regulators here need to be especially careful not to let their pride in Yamanaka's achievement affect their critical faculties, or overwhelm them in national fervour," says Douglas Sipp, who researches stemcell ethics and regulation at the RIKEN Center for Developmental Biology in Kobe, Japan.

Most stem-cell researchers are convinced that iPS cells have a long way to go before they are ready for the clinic, in part because of concerns that the cells might carry a heightened risk of producing malignant growths. "These kinds of studies should be done many times on hundreds of animals that are then followed long term - a year or more - for safety," says Paul Knoepfler, a stem-cell researcher at the University of California, Davis.

The first clinical trial of cells derived from iPS cells will probably take place in Japan next year. Masayo Takahashi of the RIKEN Center for Developmental Biology plans to use such cells to treat retinal diseases, work that seems to be proceeding cautiously and transparently. Of greater concern is the risk that some clinicians might take advantage of the hype surrounding iPS cells and start to offer untested treatments, in the same way that adult stem cells have become a booming, unregulated business 8 . "In theory, anyone can buy human iPS-cell production kits and starter cells," says Knoepfler. "All it would take is one negative patient outcome to set the field back for years".

"As we have seen from other forms of stemcell pseudomedicine," adds Sipp, "if there is money to be made, someone will probably begin trying to market them." -

1. Abbott, A. Nature 490, 151-152 (2012).

2. Cyranoski, D. Nature http://dx.doi.org/10.1038/ nature.2012.11584 (2012)

3. Moriguchi, H., Mihara, M., Sato, C. \& Chung, R. T. in Embryonic Stem Cells - Recent Advances in Pluripotent Stem Cell-Based Regenerative Medicine (ed. Atwood, C.) 359-370 (InTech, 2011).

4. Moriguchi, H., Zhang, Y., Mihara, M. \& Sato, C. Sci. Rep. 2, 537 (2012).

5. Takahashi, K. et al. Cell 131, 861-872 (2007).

6. Thenappan, A. et al. Hepatology 51, 1373-1382 (2010).

7. Moriguchi, H. \& Sato, C. Nature 457, 257 (2009)

8. Cyranoski, D. Nature 484, 149-150 (2012) 